\title{
THE EFFECT OF THYROXIN UPON THE METABOLISM OF ISOLATED NORMAL AND MALIGNANT TISSUE
}

\author{
By OVID O. MEYER, CLAIRE McTIERNAN AND JOSEPH C. AUB \\ (From the Medical Laboratories of the Collis P. Huntington Memorial Hospital \\ of Harvard University, Boston)
}

(Received for publication January 16, 1933)

In the course of an extended study of the influence of the internal secretions upon tissue metabolism, the thyroid influence seemed particularly significant. Here, therefore, is presented a detailed report of its effect not only upon a parasitic tumor tissue, but also upon the liver tissue of the host.

The effect of the hormones upon tumor growth has been investigated extensively by others but the effect upon the metabolism of the tumor has received little or no attention. Several reports of the effect of thyroxin upon the metabolism of various normal isolated tissues have been made since 1924, but the results have been somewhat contradictory. Ahlgren (1) reported that thyroxin increased the metabolic rate of tissues of frogs in vitro as measured by acceleration of the reduction of methylene blue. In 1925 he reported that thyroxin increased the oxygen consumption of thyroid-deprived muscle, and pituitrin in proper concentration acted similarly. Reinwein and Singer (2) found an increase in the oxygen consumption of surviving liver cells after addition in vitro of thyroid extract but Paasch and Reinwein (3) found no effect upon the surviving diaphragm of the rat. Wohlgemuth and Klopstock (4) noted very striking increases in the oxygen consumption of skin with inhibition of anaerobic glycolysis after administration in vitro of thyroid. Hopping (5) reported increase in the metabolism of alligator blood of 150 to 190 per cent after injection of thyroxin but no effect from the direct addition of this substance to the blood. Fleischmann (6) found slight increase in the glycolysis of leukocytes in exudate of animals but unchanged respiration after administration in vitro of thyroxin. Anselmino, Eichler and Schlossmann (7) noted maximum effects of injected thyroxin upon isolated kidney tissues at the end of 72 hours. This effect was chiefly an increase in the anaerobic glycolysis. They discerned no significant increase in the oxygen consumption of liver or spleen and only slight increase in the oxygen consumption of kidney. The anaerobic glycolysis in the liver and spleen was not increased. Dresel (8), however, a year before, reported somewhat different results in isolated rat tissues after injection of thyroxin. He noted an increase in the oxygen consumption of liver as great as 200 per cent on the third day after the injection with slight decrease in the anaerobic glycolysis. The oxygen con- 
sumption of the kidney was increased 20 to 25 per cent with no appreciable rise in the anaerobic glycolysis. Foster (9) reported appreciable decrease in the oxygen consumption of isolated rat diaphragm after thyroidectomy. Measurements were made by the Warburg method in modified Ringer's solution. McEachern and Andrus (10) have recently shown that the oxygen consumption of isolated beating auricles was increased in thyrotoxic guinea pigs to a maximum of about 20 per cent. The measurements were made in a modified Warburg respirometer. Previously they (11) had reported, confirming the observation of $\mathrm{J}$. $\mathrm{K}$. Lewis, that these isolated hearts of thyrotoxic animals beat more rapidly than normal.

Thus, it is quite obvious that to date there is some discrepancy of opinion regarding the effect of thyroxin upon isolated normal tissues though the majority of results would lead one to believe that it does increase the oxygen consumption when administered in vivo. Whether it produces metabolic effect in vitro is highly doubtful. As for the effect upon malignant tissue metabolism there are, to our knowledge, no data and it is the primary purpose of this communication to show the effect upon transplanted malignant tumor tissue. At the same time, the effect of thyroxin injections upon the normal liver tissue will be shown.

\section{METHOD OF STUDY}

Throughout this investigation pure strain, inbred, tumor susceptible black mice, kept under identical conditions, have been used. The age of the mice at the time of the experiments varied between 3 and 15 months, by far the greater number being 4 to 8 months old, and the average about 7 months. It has been found (12), however, that within rather wide limits the age of the mouse has little effect upon the metabolism of the isolated tissues. This confirms Hawkins (13), who found that the metabolism of isolated liver tissue of rats was similar at different ages, except in the very young ( 3 to 21 days old). Furthermore, we have found the metabolism of tumor tissue two weeks old to be no different from that five weeks old.

For nearly all of the experiments Sarcoma No. 180 has been the tumor used, though some determinations have been made upon Carcinoma No. 63. This sarcoma has little stroma, is made up chiefly of round tumor cells, possesses a fair blood supply, and virtually no nerves. It is a very satisfactory tumor for it is easily transplanted and grows rapidly in more than 90 per cent of the transplants, attaining a suitable size for experimental purposes in two to three weeks. In these experiments, tumors of this age have been used in almost all instances, at which time there is plenty of good viable tissue so that suitable sections can be cut with a razor blade and metabolic measurements made.

Crystalline thyroxin (Squibb) in alkaline solution was administered subcutaneously to the experimental mice in varying doses- -0.2 to $0.01 \mathrm{mgm}$. daily for periods ranging from 3 to 51 days. Most of the mice received what seemed to be the most satisfactory doses, either 0.02 or $0.04 \mathrm{mgm}$. for periods of 8 to 15 days. Thus the tumors were usually a week or more old before thyroxin was given. All injections were made in the abdomen, away from the site of the tumor implant. Tumors of a similar age were used in the control experiments.

During the time of thyroxin administration the mice almost always became 
thin and more active than normal though they were very well fed, receiving grain with cod liver oil, milk, and rat biscuit. One or more of these foods was present in the cages at all times.

The measurements of the metabolism were made with the Warburg modification of the Haldane-Barcroft blood gas apparatus. With this apparatus it was possible to measure the oxygen consumption and carbon dioxide production of respiration, and the anaerobic glycolysis with sufficient accuracy for our purpose. The details of the methods are well described by Warburg (14) and also by Richardson (15) and we have closely followed their procedures.

In our hands, there was an average difference of not over 5 per cent for the oxygen consumption measurements in consecutive duplicate experiments, whereas the average variation was about 10 per cent for carbon dioxide figures, aerobically and anaerobically. Consequently, the respiratory quotient is distinctly less reliable than the oxygen consumption, and therefore of less significance except where a consistent change of considerable magnitude exists. Because of this factor of error, stress is laid upon the results for oxygen consumption rather than for the respiratory quotient. However, the similarity of the average figures in different groups of controls is surprisingly constant despite variation in some of the individual experiments.

When the mouse was ready for an experiment, it was killed by a blow to the head and the throat immediately cut to permit free flow of blood. The tumor and liver of the animal were removed as rapidly as possible, put in Ringer's solution, and then sectioned with a razor blade. Sections were cut thin enough so as not to exceed $0.5 \mathrm{~mm}$. in thickness. They were then transferred to the manometer vessels, containing Ringer-phosphate solution with 0.20 per cent glucose for the aerobic determinations. The vessels for anaerobic glycolysis contained Ringer's solution with $0.15^{1}$ per cent glucose and 0.20 per cent sodium bicarbonate. After connection of the vessels containing the tissues with the manometers and instillation of the appropriate gas through the manometer (oxygen into the manometers used to measure respiration, and nitrogen with 5 per cent carbon dioxide into those used for measuring glycolysis anaerobically) the whole was transferred to a water bath regulated to $37.5^{\circ} \mathrm{C}$. It must be understood, of course, that two sets of manometers were used, one containing liver tissue and the other tumor tissue. These were set up simultaneously, and the measurements of the liver and tumor from the same mouse were made simultaneously in all cases. With two people working, the entire procedure of setting up the experiment from the time the mouse was killed until the twelve manometers were in the water bath, required approximately twenty minutes.

After a twenty minute period of shaking the manometers in the water bath to permit stabilization, the first reading was made and thereafter the changes in the column of Brodie's solution were noted every ten minutes for a period of one hour.

After an experiment was completed, the tissues were removed, put in individual glass containers, and dried in an electric oven at $105^{\circ} \mathrm{C}$. for two hours. They were subsequently weighed and the calculations (15) made to obtain the figures for oxygen consumption and carbon dioxide production in cubic millimeters per milligram of tissue, dry weight, per hour.

The experiments were done on fasting and non-fasting mice and, likewise,

${ }^{1}$ Several duplicate anaerobic experiments with 0.20 per cent glucose showed the carbon dioxide production to be about 10 per cent higher than in a solution with 0.15 per cent glucose. 
Chart 1

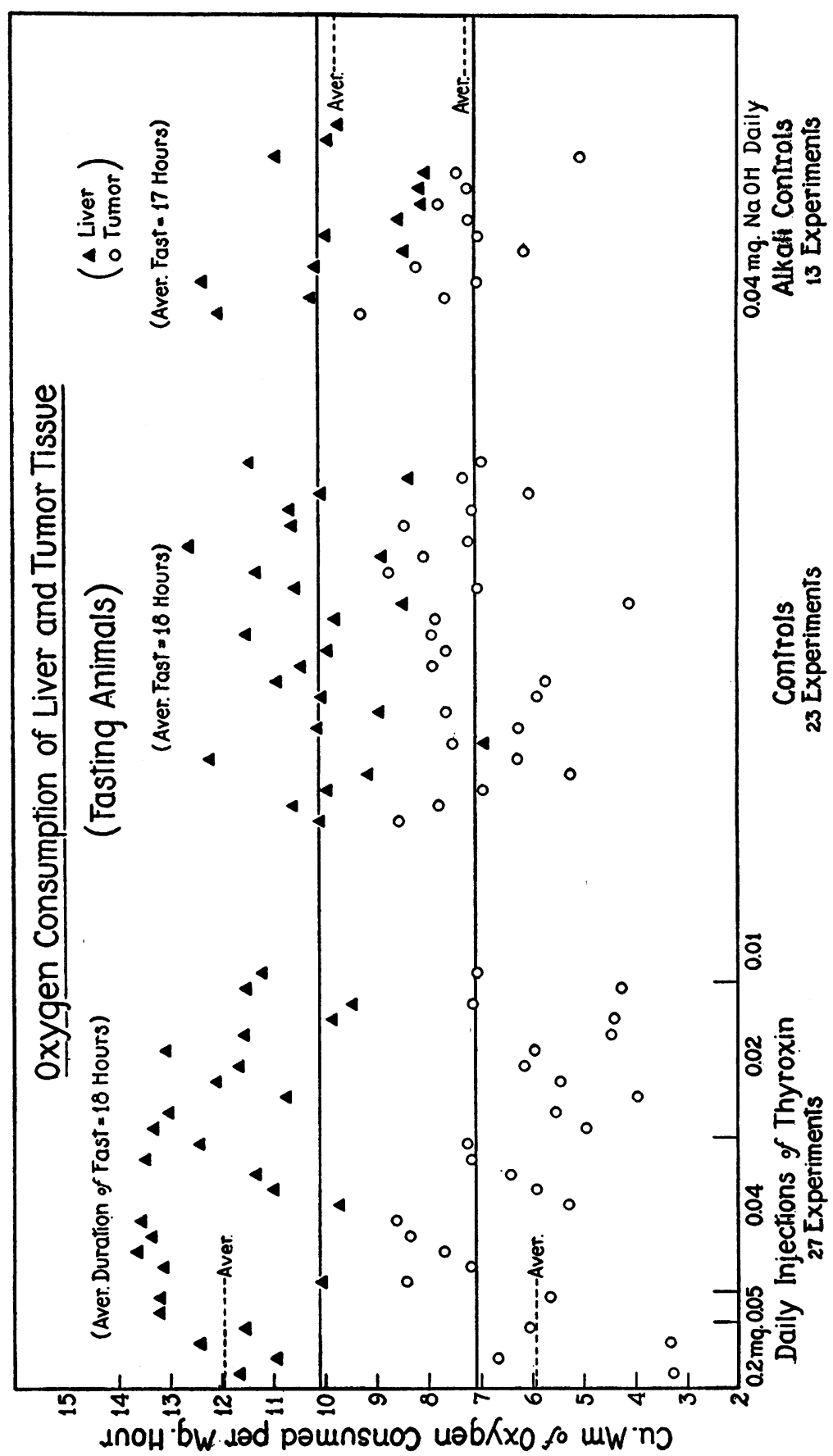


Chart 2

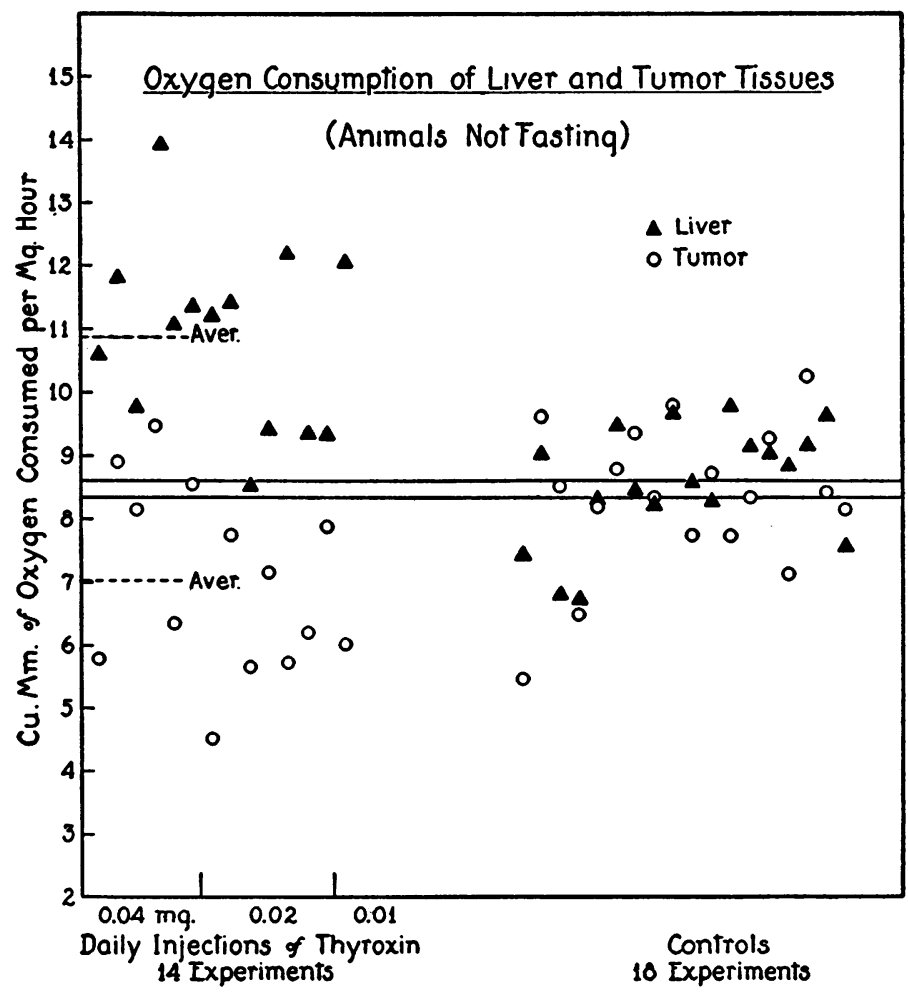

In Charts 1, 2 and 3 each triangle in black represents a single experiment upon liver tissue; the circle just below, in each instance, represents the tumor tissue from the same mouse, and the measurement of the oxygen consumption of both was done simultaneously. The upper solid line across each chart represents the average oxygen consumption of the liver tissues of the uninjected controls, the lower solid line in each case represents the average of the tumor tissues of the same controls. The upper broken lines, out from the sides, represent the average oxygen consumption of the liver tissues of injected mice; the lower, the average for the tumors of the same animals.

there were two similar groups of controls. The fasting periods ranged from 6 to 24.5 hours, the average period being 17 to 18 hours for both the controls and thyrotoxic mice. Twenty-seven fasting mice received thyroxin and these were controlled by twenty-four fasting mice. Fourteen experiments were done on non-fasting mice and these were controlled by eighteen fed animals.

Thirteen mice of a group were given $0.04 \mathrm{mgm}$. of sodium hydroxide in dilute solution, subcutaneously, for periods of 10 to 20 days. These mice served as further controls, for the amount of alkali injected was equivalent to the amount in the thyroxin solution of $0.04 \mathrm{mgm}$. concentration. These mice were fasted an average period of $\mathbf{1 7}$ hours and the results must, therefore, be compared with those of the fasting mice that received thyroxin. 


\section{RESULTS}

The results were quite striking, with differences of sufficient degree to be significant, and consistent enough to be reliable. There was distinct increase in the oxygen consumption of liver after thyroxin administration, which averaged about 20 per cent above normal. This increase was not invariable but occurred in 76 per cent of the observations. The greatest oxygen consumption occurred in the fasting group but the percentage increase over the controls was approximately the same as in the non-fasting animals. The respiratory quotients were not affected in any appreciable degree. The anaerobic glycolysis for the liver was distinctly increased in thyrotoxic mice.

More surprising than these results, however, was the effect upon the tumor metabolism. In 19 of 27 fasting animal experiments, there was distinct decrease in the oxygen consumption after thyroxin. The average of all experiments showed this to be approximately 16 per cent below normal. All the rest fell within the normal range with five distinctly higher than the average of all controls. In no instance was there an oxygen consumption greater than that found in the normal control group. In the nonfasting group 11 of 14 had an oxygen consumption below the average of the controls with none higher than that commonly noted in the tumors of the normal animals.

The results for the oxygen consumption of tumor and liver of control mice, controls injected with alkali, and of mice injected with thyroxin, are graphically shown in Charts 1 and 2. Chart 1 shows the results when the mice were fasted, Chart 2 those when they were not fasted. That the difference between the means is significant is shown by calculating the probability according to Fisher's (16) method adapted for small samples. The value of $P$ in each case is less than 0.01 , indicating that the difference between the means is significant.

The respiratory quotient was increased because of the decrease in oxygen consumption; the carbon dioxide actually produced was within the range of normal. Table I shows this.

The anaerobic glycolysis for the tumors was increased to a very slight and insignificant degree. This result, however, furnished a check, though not an absolute one, for ruling out the possibility of there being a fundamental difference in the metabolic activity of the tumor tissue after thyroxin injection. The figures for the complete metabolism, including the glycolysis for all experiments, are here shown in Table $I$.

Some of the tumors of the thyrotoxic mice have been examined by Dr. Shields Warren and he has noted no significant difference in these and tumors of control mice. The number of mitotic figures is not appreciably decreased and the tumors appear to be fully as malignant. Still, the tumors seem to grow somewhat more slowly when thyroxin is administered. This is only an impression, however, as actual statistical measurements 
OVID O. MEYER, CLAIRE MCTIERNAN AND JOSEPH C. AUB

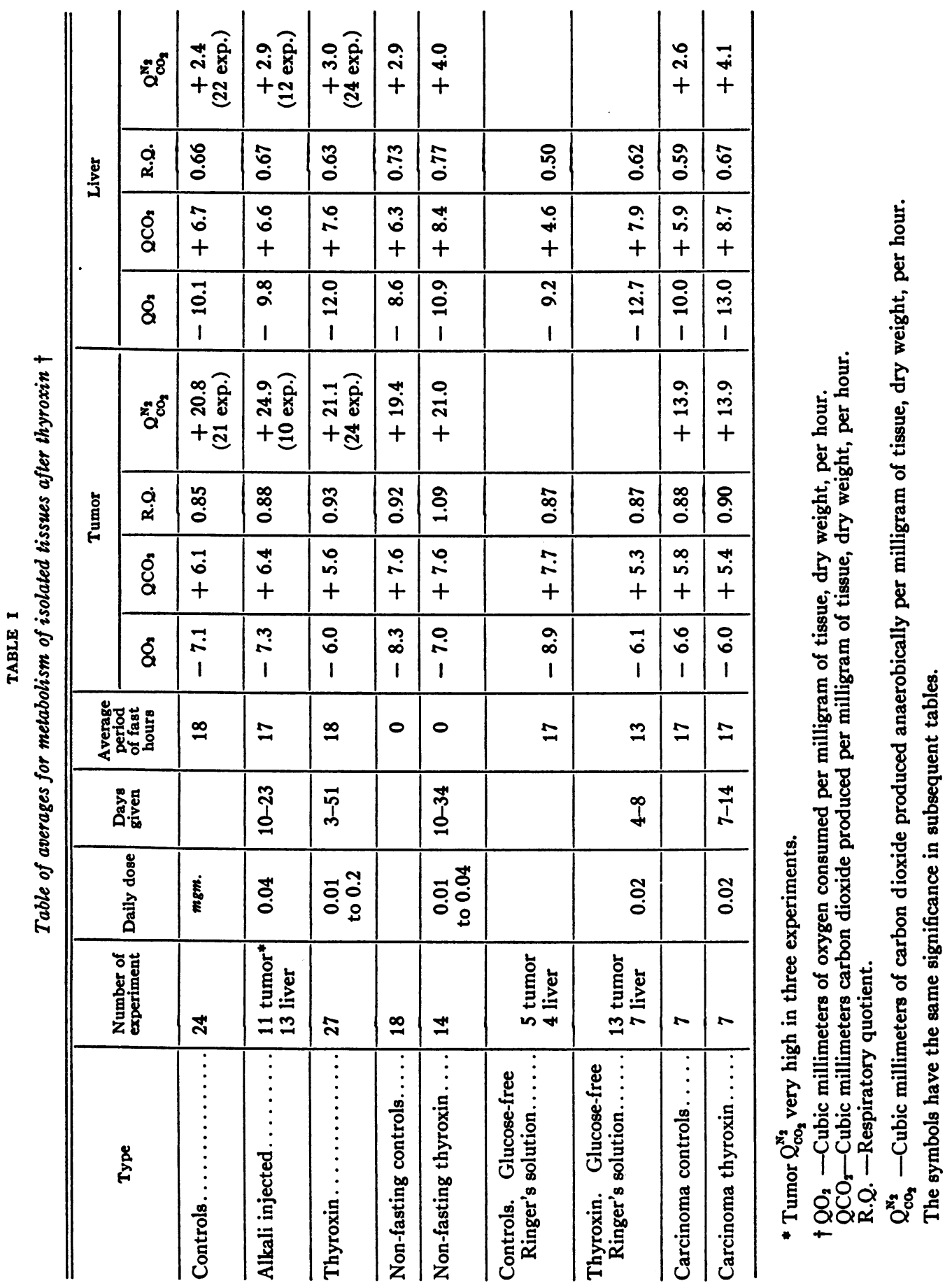


have not been made, but this is in accord with the finding of Gilroy (17) who noted inhibition of tumor growth as a result of thyroxin administration. In no instance, however, did we find evidence of regression of the tumors.

The possibility of the aerobic glycolysis of the tumor being increased to compensate for the decrease in oxygen consumption was considered and ruled out by ten controlled determinations on mice injected with thyroxin, using the method described by Negelein (18).

The possibility of the aerobic glycolysis being increased was, furthermore, ruled out by a series of experiments where the metabolism of isolated liver and tumor was determined for control and thyroxin injected mice, in Ringer's solution containing no glucose. Determinations of anaerobic glycolysis were made in only a few instances as it is well known that it is very much less than normal for the tumor, and slightly less for liver, when glucose is not present in the medium. This we had confirmed several times in previous experiments. The results for respiration, however, are given in Table $I$ and it is obvious that in very striking degree they confirm the other experiments listed in the same table. That is, the oxygen consumption of the liver is still increased and that of the tumor is decreased. Hence, because these similar results occur in Ringer's solution without glucose, where tumor glycolysis is virtually absent, one may conclude that the aerobic glycolysis does not compensate for the low oxygen consumption.

The metabolism of the entire mouse before and after thyroxin administration was determined in eight instances by Dr. William T. Salter by the open circuit method, using Carpenter's modification of the Haldane apparatus for gas analysis, and the increase in metabolism after thyroxin corresponded to the increase in the isolated liver tissue of the same mice. Where no increase in the total metabolism resulted (two cases) the tissue metabolism was normal.

\section{Carcinoma}

In order to study whether this sarcoma (No. 180) might be a tumor peculiar in its response or lack of usual response to thyroxin, seven black mice bearing Carcinoma C. 63 were each given $0.02 \mathrm{mgm}$. of thyroxin subcutaneously each day for 7 to 14 days and the tissue metabolism measured. The average fasting time was 17 hours. The results for oxygen consumption of each experiment are graphically shown in Chart 3 , and the summarized figures in Table I.

The oxygen consumption for the liver was very distinctly increased in six of the seven experiments, and decreased below the average of the controls in six of the seven tumors. The anaerobic glycolysis and respiratory quotient for the liver, however, were increased. The respiratory quotient for the tumor was again increased, but again this was due to the decreased oxygen consumption. The anaerobic glycolysis, in this tumor, as for the sarcoma, was not significantly affected by thyroxin. 
The depression of oxygen consumption for sarcoma (fasting and nonfasting), and carcinoma, occurred in more than three-fourths of the experiments. The degree of depression varied but it averaged twenty-five per cent below the average figure for oxygen consumption of the respective

Chart 3

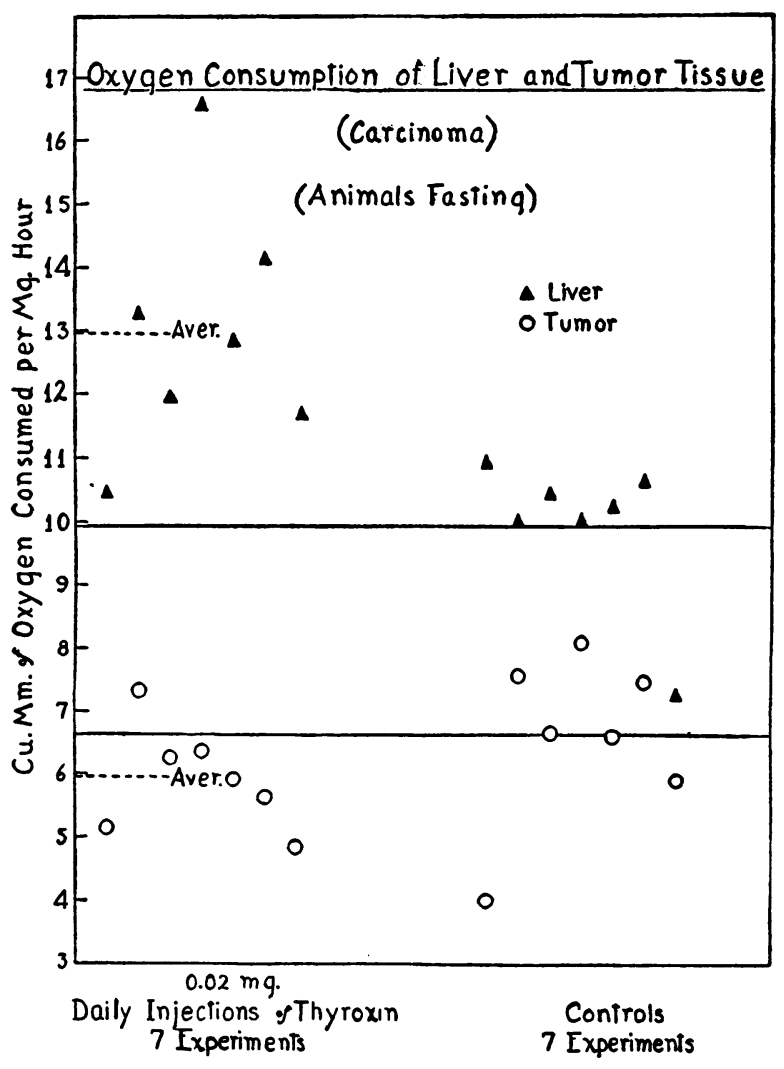

sets of controls. If the one-fourth of the experiments that showed no depression is included, the average oxygen consumption for all tumors is 15 per cent below the average of their respective controls. These figures do not include the results from the experiments done in sugar free Ringer's solution, though the depression in this group is fully as great.

The recorded results for liver were very constant and this was really anticipated. The effect of thyroxin upon the tumor, or possibly its lack of effect, that is, a failure to increase the metabolism, is unexpected, however, and we have no satisfactory explanation for it at this time.

Naturally enough, the question arose as to whether or not the virtual absence, or inadequacy, of the nerve supply was a factor. If the tumor results had been absolutely negative and there had been no depression of 
the oxygen consumption, this would seem more likely. Ring, Dworkin and Bacq (19) found that the basal metabolism was as much increased in cats, after removal of the thyreo-sympathetic chains, as in normal cats after thyroxin administration. Riml and Wolff (20) also found that cutting of various nerves did not alter the effect of thyroxin upon metabolism. Aub, Bright, and Uridil (21) in 1922 concluded that thyroxin stimulated resting cells directly. Nevertheless, despite the unlikelihood of the lack of nerves being the factor which resulted in failure of increase in tumor metabolism, it was decided to denervate a dog's kidney, and after a suitable period of thyroxin administration to measure the metabolism of the isolated tissue.

Three dogs, weighing between 36 and 41 pounds ( 16 to 20 kilos) were given thyroxin after denervation of the left kidney and the metabolism of the cortical tissue of the denervated and normal kidney was compared. At the time of the denervating operation, which was done under sodium amytal and ether anesthesia, a small section from the cortex of the left kidney was removed and the metabolism of this tissue immediately measured by the Warburg method. After a minimum postoperative period of two weeks, thyroxin was given intramuscularly until the dog had received a total of 28 to $44 \mathrm{mgm}$. over a period of 9 to 13 days. During the thyroxin administration, the dogs became nervous and very thirsty. Two of the three lost weight despite adequate amounts of food and water and all three developed persistent diarrhea. Each dog was killed by injection of air into the jugular vein and the kidneys were removed as rapidly as possible. Sections of the kidneys and of the ureter, vein, and artery were examined microscopically to be certain that they were not diseased and that denervation had been complete. One small nerve was found in the third operated dog, but as this was very small it was thought that for practical purposes the kidney might be considered as denervated. The results resembled the other two and they are included in the table.

The metabolism of the cortical tissue from the denervated kidney and the right kidney, which was used as a control, were measured simultaneously. The average results are given in Table II and it will be noted that denervation has not influenced the metabolism.

The average oxygen consumption for the cortex of the three kidneys before operation was $-11.6 \mathrm{cu}$. $\mathrm{mm}$. per mgm. of tissue per hour. Thus,

TABLE II

Metabolism of isolated dog's kidney cortex after thyroxin (Average of three experiments)

\begin{tabular}{c|c|c|c|c|c|c|c}
\hline \hline \multicolumn{3}{c|}{ Left kidney cortex (denervated) } & \multicolumn{4}{|c}{ Right kidney cortex (control) } \\
\hline $\mathrm{QO}_{2}$ & $\mathrm{QCO}_{2}$ & $\mathrm{R} . \mathrm{Q}^{\mathrm{N}}$ & $\mathrm{Q}_{\mathrm{CO}}^{\mathrm{N}}$ & $\mathrm{QO}_{2}$ & $\mathrm{QCO}_{2}$ & $\mathrm{R} . \mathrm{Q}_{2}$ & $\mathrm{Q}_{\mathrm{CO}}^{\mathrm{NO}_{2}}$ \\
\hline-13.4 & +11.4 & 0.85 & +3.9 & -13.1 & +11.1 & 0.86 & +3.4 \\
\hline
\end{tabular}


the increase after thyroxin was not very striking, but the significant thing is that the results are similar for the denervated and normal tissues. These experiments apparently furnish further evidence that the failure to produce an increase in the metabolism of tumors is not due to the lack of innervation.

The possibility of the anesthesia acting as a depressant upon the oxygen consumption in these observations on the dog has been ruled out by further control experiments where the metabolism was measured after some normal animals were killed by air injection and others by anesthesia.

\section{COMMENT}

The results given above largely speak for themselves. The explanation for these results, however, is not as yet apparent. That thyroxin should stimulate the metabolism of isolated liver tissue is rather to be expected, but the failure to act similarly, in any instance, upon tumor metabolism is at present unexplainable. Still more interesting is the fact that not only is there no such effect in any case, but thyroxin actually depresses the metabolism in the majority of the experiments. The lack of innervation does not explain this result and apparently the reason lies within the tumor itself. One may offer the hypothesis that within malignant tissue there is some unknown factor which causes that tissue to fail to respond, or to respond in an unusual manner, to thyroxin. What this unknown factor may be cannot as yet be demonstrated. Further study, possibly along chemical lines, may be necessary. It must be appreciated, of course, that in these experiments we have been dealing with a transplanted parasitic tissue. Whether spontaneous tumors respond similarly is yet to be determined.

It is interesting, in view of this effect of thyroxin, to consider that Scharles and Salter (22), working in this laboratory, have recently isolated a glycogen splitting enzyme from this Sarcoma No. 180 and have found that after administration of thyroxin, in the same manner and dosage as has been used in this investigation, the concentration of this enzyme was increased 150 per cent. What relation there is between these two observations is not yet clear.

\section{CONCLUSIONS}

1. Thyroxin administration to mice in vivo produces an average increase of more than 20 per cent in the oxygen consumption of isolated liver tissue and a distinct increase in the anaerobic glycolysis. The respiratory quotient is not strikingly affected.

2. Thyroxin failed in all instances to stimulate the metabolism of transplanted mouse tumors, Sarcoma No. 180, and in more than three-fourths of them it produced depression of the oxygen consumption which averaged 25 per cent below the normal. Carbon dioxide production by respiration and by glycolysis was not significantly affected. 
3. The aerobic glycolysis of this sarcoma is not increased after thyroxin administration.

4. The effect of thyroxin upon the metabolism of mouse Carcinoma No. 63 is similar to its effect upon sarcoma. Here the oxygen consumption was decreased in 6 or 7 experiments.

5. The respiratory metabolism of the tumor is depressed and that of liver accelerated in Ringer's solution without added glucose, as in Ringer's solution containing glucose.

6. The metabolism of the cortex of denervated and of normal kidneys of the dog is similar after thyroxin administration.

7. Apparently this unusual metabolic effect of thyroxin upon tumors is not due to the lack of innervation but to some unknown factor within the tumor tissue itself.

8. It is an impression that thyroxin inhibits the growth of Sarcoma No. 180 , to a moderate degree, but in no instance did it cause complete regression of tumors.

\section{BIBLIOGRAPHY}

1. Ahlgren, G., Klin. Wchnschr., 1924, iii, 667. Uber die Einwirkung des Insulins, Adrenalins, Thyroxins und Pituitrins sowie Gewisser Pharmaka auf die Gewebeatmung.

Skandinav. Arch. f. Physiol. (Supp.), 1925, xlvii, 225. Der Tierischen Gewebsoxydation sowie ihrer Beeinflussung durch Insulin, Adrenalin, Thyroxin und Hypophysepräparate.

2. Reinwein, H., and Singer, W., Biochem. Ztschr., 1928, cxcvii, $152 . \quad$ Studien über Gewebsatmung. IV. Der Einfluss von Thyroxin, Adrenalin und Insulin auf den Sauerstoffverbrauch überlebender Leberzellen.

3. Paasch, G., and Reinwein, H., Biochem. Ztschr., 1929, ccxi, 468 . Studien über Gewebsatmung. V. Der Einfluss von Thyroxin, Adrenalin und Insulin auf den Sauerstoffverbrauch von überlebendem Rattenzwerchfell.

4. Wohlgemuth, J., and Klopstock, E., Biochem. Ztschr., 1926, clxxv, 202. Die Fermente der Haut. V. Atmung und Glykolyse der Haut und ihre Beeinflussung durch Hormone.

5. Hopping, A., Proc. Soc. Exper. Biol. and Med., 1931, xxviii, 726. Action of Thyroxin on Tissue Metabolism.

6. Fleischmann, W., Biochem. Ztschr., 1927, clxxxvii, 324. Zur Frage der Beeinflussung des Zellstoffweschels durch das Hormon der Schildrüse. (Versuche an Leucocyten.)

7. Anselmino, K. J., Eichler, O., and Schlossmann, H., Biochem. Ztschr., 1929, ccv, 481. Uber den Einfluss des Thyroxins auf den Stoffwechsel überlebènder Gewebe.

8. Dresel, K., Klin. Wchnschr., 1928, vii, 504. Uber das Wesen der Oxydationssteigernden Wirkung des Thyroxins.

9. Foster, G. L., Proc. Soc. Exper. Biol. and Med., 1927, xxiv, 334. A Note on Tissue Respiration in Relation to Thyroidectomy.

10. McEachern, D., and Andrus, E. C., J. Clin. Invest., (Proc.) 1931, x, 653. Direct Measurements of the Oxygen Consumption of Isolated Beating Auricles from Normal and Thyrotoxic Guinea Pigs. 
11. Andrus, E. C., McEachern, D., Perlzweig, W. A., and Herman, S., J. Clin. Invest., (Proc.) 1930, ix, 16. Comparative Sensitivity to Oxygen Want and to Sodium Lactate of the Hearts of Normal and Thyroxinized Animals.

12. Meyer, O., McTiernan, C., and Aub, J. In press. Am. J. Cancer Research.

13. Hawkins, J. A., J. Gen. Physiol., 1928, xi, 645. The Metabolism of Liver Tissue from Rats of Different Ages.

14. Warburg, O., Uber den Stoffwechsel der Tumoren. Verlag von Julius Springer, Berlin, 1926.

15. Richardson, H. B., Physiol. Rev., 1929, ix, 61. The Respiratory Quotient.

16. Fisher, R., Statistical Methods for Research Workers. Oliver and Boyd, Edinburgh, 1930.

17. Gilroy, E., Biochem. J., 1930, xxiv, 1181. Comparison of the Effects of Arginine and Thyroxine upon Tumour Growth-Rate in the Mouse.

Ibid., 1930, xxiv, 1659. Further Observations upon the Correlation Between the Arginine and Vitamin B Content of Diets, and the Effect of Thyroxine upon Tumour Growth.

18. Negelein, E., Biochem. Ztschr., 1925, clviii, 121, Versuche über Glykolyse.

19. Ring, G. C., Dworkin, S., and Bacq, Z. M., Am. J. Physiol., 1931, xcvii, 315. Basal Metabolism After Thyroxin in Sympathectomized Animals.

20. Riml, O., and Wolff, H. G., Arch. f. Exper. Path. u. Pharmakol., 1930, clvii, 178. Zur Frage des Angriffspunktes der stoffwechselsteigernden Schilddrüsenwirkung.

21. Aub, J. C., Bright, E. M., and Uridil, J., Am. J. Physiol., 1922, 1xi, 300. Studies upon the Mechanism of the Increased Metabolism in Hyperthyroidism.

22. Scharles, F., and Salter, W. In press. Am. J. Cancer Research. Tumor Amylase: The Effect of Various Hormones and Chemical Agents. 